\section{Acute renal failure during interferon treatment}

Drs I H Fahal, N Murry, P Chu, and G M BeLL (Royal Liverpool University Hospital, Liverpool L7 8XP) write: Interferon alfa-2b is used as maintenance treatment in patients with multiple myeloma.' Although renal toxicity is rare, mild proteinuria is common. ${ }^{2}$ We present the case of a patient who developed acute renal failure during treatment with recombinant interferon alfa- $2 b$.

A 49 year old woman was admitted with a week's history of nausea, vomiting, and declining urinary output. Two years previously an IgG $\kappa$ multiple myeloma had been diagnosed. Ten months before admission maintenance treatment with recombinant interferon alfa-2b (intron A) $3 \mathrm{MU}$ was started subcutaneously thrice weekly. She took additionally only ferrous sulphate and vitamin $B$ complex.

On admission she was pale and apyrexial, with a blood pressure of $120 / 70 \mathrm{~mm} \mathrm{Hg}$, a sinus tachycardia of 100 beats $/ \mathrm{min}$, and a central venous pressure of $1 \mathrm{~mm} \mathrm{H} \mathrm{H}_{2} \mathrm{O}$. Cardiovascular, respiratory, and abdominal examination showed nothing abnormal. Investigations showed: serum sodium $127 \mathrm{mmol} / \mathrm{l}$ (normal 136-148), potassium $4 \cdot 2 \mathrm{mmol} / \mathrm{l}(3 \cdot 8-5 \cdot 0)$, blood urea $26.8 \mathrm{mmol} / \mathrm{l}(2 \cdot 5-6 \cdot 6)$, and serum creatinine $1020 \mu \mathrm{mol} / \mathrm{l}$ (62-124). Haemoglobin was $90 \mathrm{~g} / \mathrm{l}$, white cell count $11.8 \times 10^{6} / \mathrm{h}$, platelet count $405 \times 10^{6} / 1$, and erythrocyte sedimentation rate $130 \mathrm{~mm}$ in first $\mathrm{h}$, and plasma viscosity was raised $(2.21 \mathrm{mPa} . \mathrm{s})$. A coagulation screen gave normal results. Serum IgG was raised at $35 \mathrm{~g} / \mathrm{l}(5-14)$, with a monoclonal IgG $\kappa$ paraprotein. Repeated infection screens were negative. Urine examination revealed considerable protein $(++)$ but no blood or myoglobin. Renal biopsy suggested severe tubular cell damage, but no tubular casts or myeloma and no amyloid deposits or urate crystals were seen.

Interferon was discontinued and the patient managed conservatively with dopamine and fluid restriction. Urine output gradually improved and she underwent a polyuric phase with resolution of her renal failure.

Mild proteinuria, ${ }^{3}$ the nephrotic syndrome, ${ }^{4}$ and acute interstitial nephritis ${ }^{5}$ have been reported in association with interferon alfa. Acute tubular necrosis in this patient was possibly a toxic effect of interferon as there was no other apparent cause. The renal biopsy excluded uric acid crystals or myeloma casts causing tubular obstruction, and there was no history of nephrotoxic drug ingestion or evidence of drug rashes or eosinophilia. Renal dysfunction is known to increase the toxicity of interferon and adequate hydration is always necessary during treatment. Although the renal failure developed 10 months after the start of interferon treatment, mild dehydration secondary to vomiting might have triggered the nephrotoxicity reaction.

Interferon is used to treat haematological malignancies, ${ }^{126}$ and such adverse reactions as acute renal failure may be seen more frequently. Regular urine analysis, monitoring of fluid balance, and renal function are therefore advisable. Discontinuation should be urgently considered at early signs of renal impairment.

Mandelli F, Giuseppe A, Amadori S, et al. Maintenance treatment with recombinan interferon alfa-2b in patients with multiple myeloma responding to convention induction chemotherapy. $N$ Engl f $\mathrm{Med}$ 1990;322:1430-4.

2 Roth MS, Foon KA. Alpha interferon in the treatment of haematologic malignancies. $A m$ f Med 1986;81:871-82.

3 Quesada JR, Talpaz M, Rios A, Kurzock R, Gutterman JU. Clinical toxicity of interferons in cancer patients: a review. Clin Oncol 1986;4:234-43.

4 Selby P, Kohn J, Raymond J, Judson I, McElwain T. Nephrotic syndrome during treatment with interferon. $B M \mathcal{F} 1985 ; 290$ : 1180

5 Averbuch SD, Austin HA III, Sherwin SA Antonovych T, Bunn PA, Longo DL. Acute interstitial nephritis with the nephrotic syndrome following recombinant leucocyte A interferon therapy for mycosis fungoides. N Engl F Med 1984;310:32-5.

6 Talpaz M, Kantariian HM, McCredie K, Trujillo JM, Keating MJ, Gutterman JU Haematologic remission and cytogenetic improvement induced by recombinan human interferon alpha in chronic myelogenous leukemia. $N$ Engl 9 Med 1986 314:1065-9.

\section{Hypersensitivity vasculitis related to nicoumalone}

Drs $R$ Susano, a Garcia, A Altadill, and J Ferro (Hospital Central de Asturias, 33006-Oviedo Spain) write: Only certain allergic reactions, mainly bleeding due to depressed coagulation factors and microvascular thrombosis leading to necrosis, have so far been regarded as nicoumalone related skin reactions. ${ }^{1+}$ We report a case of vasculitis, not previously presented in the classic literature ${ }^{5-7}$ or known to the Spanish drug surveillance programme.

A 74 year old white woman with bilateral varicose veins was admitted with deep venous thrombosis, pulmonary embolism, and arrhythmia. Levels of antithrombin III and protein $\mathrm{C}$ were normal, and she was negative for antiphospholipid antibodies. There was no indication of any neoplastic disorder. Heparin was precribed and the patient was discharged after two weeks taking nicoumalone $2 \mathrm{mg} /$ day, ranitidine, and amiodarone. Three weeks late she was readmitted with six day old palpable purpura in both legs with no other clinical features. The prothrombin time was 18 seconds (control 12 seconds) and the partial thromboplastin time 35 seconds. The following investigations all gave normal findings: differential blood count, erythrocyte sedimentation rate, blood biochemistry, measurement of plasma protein complement, antistreptolysin $\mathrm{O}$, urinary sediment, cryoglobulin, and latex and antinuclear antibodies. All drugs were stopped. A skin biopsy displayed features of leucocytoclastic vasculitis. She was given prophylactic heparin and steadily improved over 15 days. The skin lesions reappeared, however, a few hours after a single dose of nicoumalone $4 \mathrm{mg}$, and the patient was finally discharged taking just subcutaneous heparin. One year later she remained free of symptoms.

While the re-exposure suggests that nicoumalone caused the vasculitis, there remains a possibility that amiodarone-capable both of immune based alterations and of interference in the metabolism of these drugs, even months after its withdrawal-might have acted as a cofactor by an unknown mechanism.

1 Koch-Weser J. Coumarin necrosis. Ann Intern Med 1968;68:1365-7.

2 McGehee WG, Klotz TA, Epstein DJ Rapaport SI. Coumarin necrosis associated with hereditary protein C deficiency. $A n n$ Intern Med 1984;101:59-60.

3 Levine MN, Hirsh J. Hemorrhagic complications of anticoagulant therapy. Semin Thromb Hemost 1986;12:39-57.

4 Cole MS, Minifee PK, Wolma FJ. Coumarin necrosis: a review of the literature. Surgery 1988;103:271-7.

5 Loeliger EA. Drugs affecting blood coagulation and hemostasis. In: Dukes MMG Beeley L, eds. Maylers's side effects of drugs, annual 12. Amsterdam: Elsevier Science, 1988:309-15.

6 Griffin JP, D'Arcy PF, Speirs CJ. Anticoagulants. In: Griffin JP, ed. $A$ manual of adverse drug interactions. 4th ed. London: Wright, Butterworth, Heinemann, 1988 137-58.

7 Magerus PW, Broze Jr GJ, Mietich JP, Tollefsen M. Anticoagulant, thrombolytic, and antiplatelet drugs. In: Gilman AG, Rall TW, Nies AS, Taylor P, eds. Goodma and Gilman's the pharmacological basis of therapeutics. 8th ed. New York: Pergamon Press, 1990:1311-31.

\section{A new skin lesion associated with intravenous streptokinase}

Drs J E Smithson, C T C Kennedy, and S Hughes (Southmead Hospital, Bristol BS10 5NB) write: We describe three patients with discrete purpuric papules following intravenous streptokinase dissimilar to skin lesions previously described. ${ }^{1-4}$ All three received aspirin $150-300 \mathrm{mg}$ daily by mouth, intravenous streptokinase $(1.5 \mathrm{MU})$, and subsequently heparin infusion for 24 hours.

Case 1-After admission a 66 year old smoker with confirmed anterior myocardial infarction developed five small non-blanching purple papules

on the dorsum of the right hand. No other rash was present and the lesions resolved spontaneously over several days. On admission the patient was taking timolol eye drops $(0.25 \%)$, and he received one oral dose of atenolol $50 \mathrm{mg}$ before the rash appeared.

Case 2-A 46 year old man with inactive ulcerative colitis and a confirmed anterioseptal infarct developed fever $\left(39^{\circ} \mathrm{C}\right)$ and a painless dark blue-black papule on the dorsum of his left hand 24 hours after admission. The fever and skin lesion both resolved over 48 hours. There was no microscopic haematuria and subsequent lipid profile was normal. The patient was taking no medication on admission and no other drugs were administered before the appearance of the rash

Case 3-A 75 year old woman with a confirmed inferior myocardial infarct developed a small papule on the dorsum of the right ring finger 24 hours after admission. Sections of the lesion stained with haematoxylin and eosin showed a subepidermal collection of neutrophils, red blood cells, and fibrin. Beneath this were superficial dermal venules showing endothelial cell swelling. Epithelial downgrowths at the periphery separated the collection of neutrophils and blood from the dermis. Complement and platelet aggregation studies were normal. On admission the patient was taking dothiepin $50 \mathrm{mg}$ at night, and received one intravenous dose of diamorphine $(5 \mathrm{mg})$ and metoclopramide $(10 \mathrm{mg})$ shortly after admission.

In all three cases the platelet count was normal and activated partial thromboplastin time was in the therapeutic range in the two men. In the third case activated partial thromboplastin time was raised but there was no evidence of spontaneous bleeding.

Although the histology is consistent with vasculitis, the distribution would be unusual for vasculitis or emboli. Such lesions have not been described with aspirin, heparin or $\beta$ blockers. These lesions do not appear to be clinically important and 